\title{
Physical versus biological control of element incorporation into biogenic carbonate: an in situ experiment in a New Zealand fjord
}

\author{
Nicola A. Beer ${ }^{1, *}$, Stephen R. Wing ${ }^{1}$, Yi Hu${ }^{2}$ \\ ${ }^{1}$ Department of Marine Science, University of Otago, Dunedin 9054, New Zealand \\ ${ }^{2}$ Advanced Analytical Centre, James Cook University, Townsville, Queensland 4811, Australia
}

\begin{abstract}
We exploit the pronounced and persistent low salinity layer in Doubtful Sound, southwest New Zealand, as a natural experimental system with sharp environmental gradients in which to study physical versus biological control of element incorporation into biogenic carbonate. Mussels Mytilus galloprovincialis transplanted to cages in the low salinity layer and saline layer in inner, mid and outer fjord habitats were used as biological integrators of physico-chemical conditions in each water mass over a period of several months. We used solution inductively coupled plasma mass spectrometry (ICP-MS) to measure the concentrations of 15 elements ( $\mathrm{Li}, \mathrm{B}, \mathrm{Mg}, \mathrm{P}, \mathrm{S}, \mathrm{Mn}, \mathrm{Fe}, \mathrm{Co}, \mathrm{Cu}, \mathrm{Zn}$, $\mathrm{Rb}, \mathrm{Sr}, \mathrm{Cd}, \mathrm{Ba}, \mathrm{Pb}$ ) in the experimental shell growth and relate spatial trends to those in salinity and elemental sources. S concentrations were consistently below detection limits while $\mathrm{Zn}$ and $\mathrm{Rb}$ showed no spatial variability. The majority of elements were subject to environmental control, likely reflecting ambient concentrations and salinity. Sr incorporation showed evidence of strong biological mediation of environmental signals via the crystal shell growth rate. These findings are a valuable addition to the growing body of literature seeking to resolve physical versus biological controls of individual trace element incorporation into biogenic carbonates, and have important consequences for their use as environmental indicators or tracers for ecological studies.
\end{abstract}

KEY WORDS: Trace elements $\cdot$ ICP-MS $\cdot$ Mussels $\cdot$ Fjord

\section{INTRODUCTION}

Concentrations of trace, minor and major elements within biogenic calcified structures may reflect environmental conditions at the time of accretion and as such have the potential to provide information on dispersal and connectivity patterns of fish (Thorrold et al. 2002) and invertebrates (DiBacco \& Levin 2000), stock structure (Campana et al. 1994), palaeoclimatic conditions (Dodd \& Crisp 1982, Gillikin et al. 2006) and anthropogenic disturbances (Gillikin et al. 2005a). However, increasing evidence suggests that in addition to physical mechanisms such as temperature and salinity, biological processes such as calcification rate are important in controlling elemental uptake and can mask or modify environmental signals (Vander Putten et al. 2000).
During molluscan shell formation, an integrated series of physiological, biochemical and crystallographic processes result in a highly organised structure of calcium carbonate crystals in an organic matrix; these processes likely occur extracellularly and in physical isolation from the seawater in the extrapallial fluid (EPF) that fills the extrapallial cavity (Wilbur 1972), although more recently cellular involvement in the biomineralisation of oyster shells has been suggested (Mount et al. 2004). Ions used in calcification are transported to the EPF via both passive and active pathways (Gillikin et al. 2005b, Carré et al. 2006) and their incorporation into the matrix is directly dependent upon their concentration in the EPF at the site of crystallisation, which is in turn controlled by the haemolymph and mantle tissues. Fractionation can occur, resulting in carbonates that do not reflect direct 
seawater precipitation (Wilbur 1972). Passive uptake occurs down a concentration gradient, although some elements (e.g. Mn, Zn, Cd, Pb) may also be transported via ion pumps (Qiu et al. 2005). Divalent ions with radii smaller than or similar to $\mathrm{Ca}^{2+}$ can substitute into the crystal lattice by diadochically replacing $\mathrm{Ca}^{2+}$ ions and may result in a lattice distortion (Goldsmith et al. 1961), potentially increasing the likelihood of subsequent incorporation of larger ions (Pitts \& Wallace 1994, Vander Putten et al. 2000, de Vries et al. 2005).

For the majority of elements, the free ion is the most bioavailable form (Phillips 1995). Ambient seawater concentrations of these ions can have varying effects on their concentrations (relative to $\mathrm{Ca}$ ) in biogenic carbonates. Early studies showed that $\mathrm{Sr} / \mathrm{Ca}$ and $\mathrm{Mg} / \mathrm{Ca}$ in mytilid mussel shells are directly related to seawater concentrations (Dodd 1965, Lorens \& Bender 1980) and a correlation has been reported between $\mathrm{Mn} / \mathrm{Ca}$ and $\mathrm{Pb} / \mathrm{Ca}$ in bivalve shells and the surrounding water (Becker et al. 2005). Incorporation of elements with a larger ionic radius than $\mathrm{Ca}^{2+}$ (e.g. $\mathrm{Ba}^{2+}$ ) may be strongly influenced by environmental factors and a direct relationship has been reported between Mytilus edulis shell $\mathrm{Ba} / \mathrm{Ca}$ and ambient $\mathrm{Ba}$ concentrations (Gillikin et al. 2006). The concentration of bioavailable free ions varies with salinity (Bruland 1983), but studies on elemental uptake by bivalves have reported conflicting effects of salinity. Salinity may influence elemental concentrations in $M$. edulis tissues through (1) increased availability in low salinity waters due to the higher capacity of freshwater to retain elements in solution or suspension; (2) different ion flux rates at different salinities, or (3) physiological responses at stressful salinities such as valve closure in osmoconforming bivalves during periods of rapid salinity decrease, which can effectively halt uptake from either dissolved or particulate phases during the periods when element availability is maximal (Phillips 1977b). At salinities $<6$ the proportion of the free $\mathrm{Cd}^{2+}$ ion in the total $\mathrm{Cd}$ pool increases and increased uptake of both $\mathrm{Cd}$ and $\mathrm{Cu}$ by $M$. edulis has been reported at lower salinities (Phillips 1976, 1977a). Some studies have suggested a minor environmental influence on $\mathrm{Sr}$ incorporation by mytilids (Rucker \& Valentine 1961, Lorrain et al. 2005, Carré et al. 2006). At low salinities $(<8)$ a direct relationship does seem to exist (Dodd \& Crisp 1982) and an increase in Sr incorporation with increasing salinity has been reported in a long-lived bivalve (Raith et al. 1996). A strong inverse relationship between $\mathrm{Mg} / \mathrm{Ca}$ and salinity has been reported in mytilid shell material (Dodd 1965), although during estuarine mixing $\mathrm{Mg}$ in solution may only differ between freshwater and saltwater at salinities <8 (Dodd \& Crisp 1982) and elsewhere minimal environmental control of $\mathrm{Mg} / \mathrm{Ca}$ has been reported (Lazareth et al. 2003, Carré et al. 2006). There is evidence for a relationship between salinity and Mn uptake in bivalve shells (Rucker \& Valentine 1961, Strasser et al. 2008a). Freshwater is enriched in Mn and Ba relative to seawater but the absence of a direct correlation between $\mathrm{Mn} / \mathrm{Ca}$ or $\mathrm{Ba} / \mathrm{Ca}$ and precipitation (and therefore runoff) suggests that the relationship is nonlinear (Lazareth et al. 2003) and interactions between environmental conditions and biological factors complicate the interpretation of $\mathrm{Mn} / \mathrm{Ca}$ in biogenic carbonates (Elsdon \& Gillanders 2003, Bath Martin \& Thorrold 2005, Strasser et al. 2008a).

Information on other elements is sparse. In an early work, Rucker and Valentine (1961) found no relationship between $\mathrm{B} / \mathrm{Ca}, \mathrm{Mg} / \mathrm{Ca}$ or $\mathrm{Cu} / \mathrm{Ca}$ in oyster shells and salinity; however Furst et al. (1976) suggested that B may vary directly with salinity in mytilid shells. No studies to date have related bivalve Li/Ca to environmental or physiological conditions but experimental studies have reported a strong positive correlation between $\mathrm{Li} / \mathrm{Ca}$ in fish otoliths and salinity (Hicks et al. 2010). Environmental effects on $\mathrm{Pb}$ uptake in mytilids are largely unknown, although an inverse relationship with salinity has been suggested (Phillips 1978).

As relationships between environmental conditions and bivalve element/Ca ratios are inconsistent, particularly for well-studied elements such as Sr and Mg, species effects are likely. Indirect effects of environmental conditions may also be important, for example through increased growth rates under optimal conditions (Gillikin et al. 2005a, 2005b). The growth entrapment model (Watson 1996) predicts that the ability of a deposited material to expel trace impurities is exceeded at high crystal growth rates, leading to increased element concentrations (Carré et al. 2006) although this model has been disputed (Foster et al. 2009). Growth rate has been reported to affect Sr incorporation in some bivalve species but not others (Swan 1957, Gillikin et al. 2005b, Foster et al. 2009); no relationship has been established between growth rate and Sr/Ca in mytilids (Lorens \& Bender 1980). Higher growth rates may also result in increased incorporation of $\mathrm{Mg}, \mathrm{Mn}$ and $\mathrm{Ba}$ in fish otoliths (Bath Martin \& Thorrold 2005, Hamer \& Jenkins 2007) and bivalve shells (Stecher et al. 1996, Carré et al. 2006) but elsewhere an inverse relationship with bivalve growth rate has been attributed to an increased ionic discriminatory ability with increased size (Strasser et al. 2008b). Similarly, increasing age has been linked to a decrease in incorporation of Sr and Mg in mytilids (Dodd 1965).

Doubtful Sound, New Zealand, represents an interesting model system in which to study fjord oceanographic and ecological processes, as the typical estuarine circulation pattern and salinity regime have been 
anthropogenically amplified. The high orographic rainfall $\left(\sim 7 \mathrm{~m} \mathrm{yr}^{-1}\right)$ and steep topography of the Fiordland region result in naturally large inputs of freshwater into the fjords (Stanton \& Pickard 1981). This results in a persistent condition of 2 distinct water masses, with a surface low salinity layer (LSL) overlying a denser saline layer (SL). The 2 water masses become progressively more mixed towards the mouths of the fjords, resulting in a steady decrease in depth and increase in salinity of the LSL along the fjord axis (Gibbs et al. 2000). In Doubtful Sound the LSL is both more pronounced and more persistent as a result of freshwater outflow from the Manapouri hydroelectric power station (HEP) outflow, which diverts nearly the entire flow from the catchments of Lakes Manapouri and Te Anau and discharges 450 to $700 \mathrm{~m}^{3} \mathrm{~s}^{-1}$ of freshwater into the head of Doubtful Sound at Deep Cove (Fig. 1). This effectively more than triples the freshwater input into the fjord (Stanton \& Pickard 1981, Bowman et al. 1999) forming a jet (Gibbs et al. 2000) that is detectable as a plume some distance outside the mouth of the fjord (Frew \& Hunter 1995, McCully et al. 1995). Typically 1 to $4 \mathrm{~m}$ in thickness but periodically extending to a depth of $12 \mathrm{~m}$ at the head of the fjord

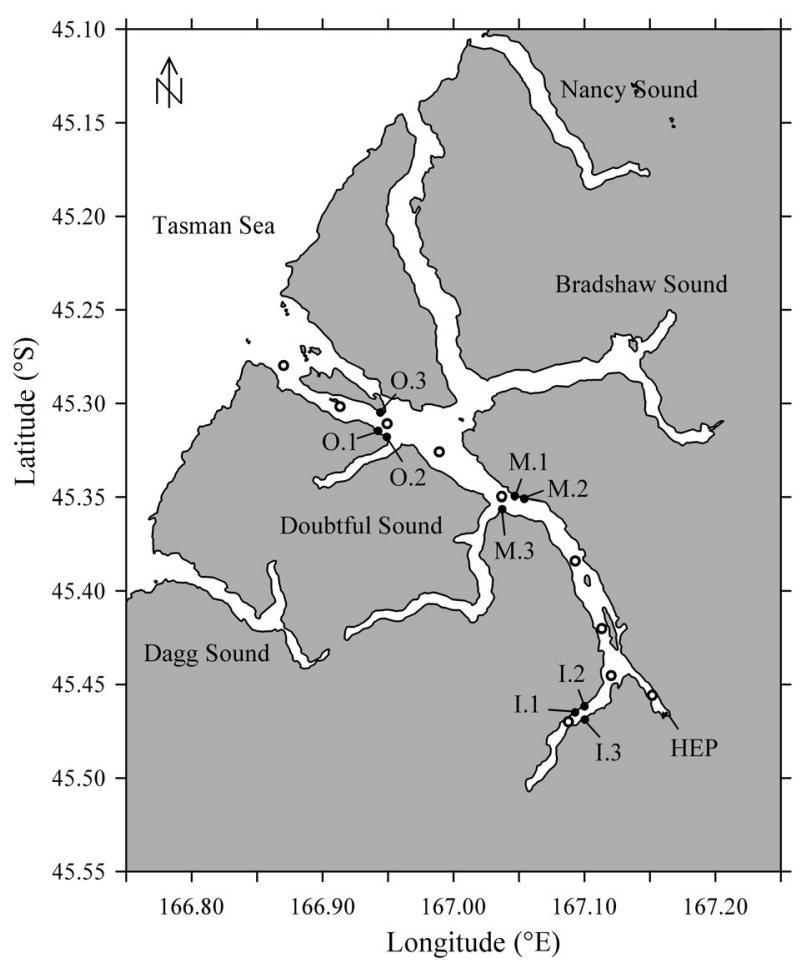

Fig. 1. Doubtful Sound, Fiordland, southwest New Zealand. (o) Oceanographic survey sites and (•) experimental mussel Mytilus galloprovincialis transplant sites in inner (I), mid (M) and outer (o) fjord habitats. HEP: tailrace outflow from the Manapouri hydroelectric power station
(Rutger \& Wing 2006), the LSL in Doubtful Sound is significantly deeper than the more naturally variable LSLs in other fjords in Fiordland and is likely one of the most pronounced in the world (Stanton \& Pickard 1981, Gibbs 2001). Unlike in other fjord systems, the LSL in Doubtful Sound is a year-round phenomenon. It creates strong environmental gradients over relatively small spatial scales, both vertically through the water column and horizontally along the fjord axis.

Outflow from the Manapouri HEP means that elemental gradients within Doubtful Sound are potentially more accentuated than in unaltered fjords in the system, as the catchment has been extended to include Lakes Manapouri and Te Anau. The surrounding mountains are predominantly igneous (Oliver 1980). As the area is geologically young, of volcanic origin, seismically active and mineral-rich, relatively high fluvial inputs from weathering and erosion are likely. Anthropogenic inputs originating from pollutants are minimised by the National Park status of the surrounding area. The scarce topsoil on the steep-sided walls lacks the macronutrients $\mathrm{N}$ and $\mathrm{P}$, which are predominantly sourced from the exchange of oceanic water over the entrance sill, and levels are significantly higher in the SL than the LSL (Peake et al. 2001). High levels of $\mathrm{Si}$ are sourced from the LSL which, when mixed with the $\mathrm{N}$ and $\mathrm{P}$-rich $\mathrm{SL}$, result in diatom blooms (Goebel et al. 2005).

The strong and persistent physico-chemical gradient between water masses in Doubtful Sound presents an exciting scientific opportunity to investigate the environmental and biological influences on trace metal uptake by biogenic carbonates in a natural system. Here we use experimental transplants across these environmental gradients to ask the question: how well is variability in the concentration of 15 elements explained by differences in environmental conditions or by differences in growth of shell carbonate? High longitudinal growth rates and tolerance to a wide range of environmental conditions render mytilid mussels well-suited to such questions (Vander Putten et al. 2000). In this study we employ mussels as biological integrators of physico-chemical conditions within the LSL and the underlying SL over a period of several months and assess the relative importance of physical and biological controls of element incorporation into shells grown in situ, under natural conditions, in a region of strong environmental gradients.

\section{MATERIALS AND METHODS}

Oceanographic surveys. Oceanographic surveys were conducted using a Seabird SBE-19 conductivity, temperature and depth (CTD) profiler, which sampled 
at $0.5 \mathrm{~s}$ intervals and was lowered at $0.5 \mathrm{~m} \mathrm{~s}^{-1}$ (Wing \& Leichter 2011). Profiles at 3 replicate sites each in the inner, mid and outer fjord habitats (Fig. 1) were used to describe the long-term average temperature-salinity climate in each habitat. As both temperature and salinity are highly variable within the LSL in response to freshwater inputs (Stanton \& Pickard 1981, Stanton 1984, 1986, Gibbs et al. 2000, Gibbs 2001), averages provided robust estimates of the range of conditions vertically through the water column and horizontally along the fjord axis. Sampling events spanned $10 \mathrm{yr}$ (1998-2008) and included periods of both high and low rainfall. Temperature was also recorded in situ for $5 \mathrm{mo}$ of the 7-mo experimental period (July-December 2006) by НOBO Temp loggers (Onset Computers) attached to each mussel transplant cage.

Mussel transplant experiment. Mussels Mytilus galloprovincialis were collected from outer Doubtful Sound in July 2006 and transplanted to cages at 3 replicate sites each in the inner, mid and outer fjord habitats (Fig. 1; see Wing \& Leichter 2011 for more detailed methods). The extent of shell growth at the start of the experimental period was marked by etching the distal margin of one valve using a triangular file. Experimental cages at $2 \mathrm{~m}$ depth were positioned within the LSL while cages at $8 \mathrm{~m}$ depth were positioned within the SL. Mussels were retrieved in February 2007 after an experimental duration of 213 d incorporating the most productive spring-summer growth period. Mortality is reported in Wing \& Leichter (2011); a sub-sample of live mussels $(\mathrm{n}=68)$ was selected for trace element analysis. The experimental shell growth was easily identifiable as the portion distal to the etched mark. Mussels were immediately frozen before the flesh was removed using Teflon-coated forceps and discarded. Growth rate was calculated as the change in shell length divided by the average shell length during the experiment for each individual (Wing \& Leichter 2011). Experimental valves were stored in individual bags for subsequent elemental analysis.

Elemental analysis. Valves were transferred to a clean laboratory where the experimental growth portion (distal to the etched mark) was clipped off using Teflon coated forceps and transferred to individual acid-washed high-density polyethylene (HDPE) vials. A solution of $15 \%$ hydrogen peroxide buffered with $0.05 \mathrm{~mol} \mathrm{l}^{-1}$ sodium hydroxide (trace element grade, Fisher Scientific) was added to each vial and microwave-assisted heating was applied for $24 \mathrm{~h}$ to remove the organic material (including the periostracum) from the shell tissue. Samples were rinsed 3 times in quartz distilled (QD) $18 \mathrm{mQ}$ water. A $1 \%$ nitric acid solution (Merck Suprapure) was then added to the vial for $10 \mathrm{~s}$ before rinsing a further 4 times with QD
Table 1. Mytilus galloprovincialis. Machine precision estimates, shown as relative standard deviation (RSD) for each element measured in mussel shells using inductively coupled plasma mass spectrometry (ICP-MS). bd: below detection limits

\begin{tabular}{|lcc|}
\hline Element & Isotope & RSD (\%) \\
\hline Lithium & ${ }^{7} \mathrm{Li}$ & 0 \\
Boron & ${ }^{11} \mathrm{~B}$ & 9 \\
Magnesium & ${ }^{25} \mathrm{Mg}$ & 1 \\
Phosphorus & ${ }^{31} \mathrm{P}$ & 1 \\
Sulphur & ${ }^{34} \mathrm{~S}$ & $\mathrm{bd}$ \\
Manganese & ${ }^{55} \mathrm{Mn}$ & 1 \\
Iron & ${ }^{56} \mathrm{Fe}$ & 3 \\
Cobalt & ${ }^{59} \mathrm{Co}$ & 3 \\
Copper & ${ }^{65} \mathrm{Cu}$ & 0 \\
Zinc & ${ }^{66} \mathrm{Zn}$ & 2 \\
Rubidium & ${ }^{85} \mathrm{Rb}$ & 10 \\
Strontium & ${ }^{88} \mathrm{Sr}$ & 2 \\
Cadmium & ${ }^{111} \mathrm{Cd}$ & 0 \\
Barium & ${ }^{138} \mathrm{Ba}$ & 0 \\
Lead & ${ }^{206} \mathrm{~Pb},{ }^{207} \mathrm{~Pb},{ }^{208} \mathrm{~Pb}$ & 5 \\
\hline
\end{tabular}

water. Samples were left to dry in a laminar flow hood before being transferred to clean acid-washed HDPE vials. Clean, dry samples were weighed and then crushed using an agate pestle and mortar and both calcite and aragonite crystalline phases were dissolved in superpure double distilled nitric acid $(65 \%$, Merck Suprapure®) and analytical reagent (AR) Grade $\mathrm{H}_{2} \mathrm{O}_{2}$ using a microwave digestion system (START D, Milestone). Concentrations of 15 elements were measured using inductively coupled plasma mass spectrometry (ICP-MS). For Fe, collision reaction interface (820-MS, Varian) was used in addition to ICP-MS to minimise polyatomic interferences. Concentrations of S were not significantly greater than instrumental detection limits and it was excluded from subsequent analyses. Concentrations of each element were converted to $\mu \mathrm{mol}$ or mmol per mol ${ }^{43} \mathrm{Ca}$. Machine precision estimates (relative standard deviation, Table 1) were calculated based on 3 replicate measurements of the same sample and were within acceptable limits for the analysis of spatial trends.

Statistical analysis. Statistical analyses were performed using PERMANOVA+ for PRIMER v.6 (PrimerE), which calculates $p$-values under permutation and therefore avoids the assumptions of normality and homogeneity of variance inherent in traditional tests (Anderson 2001). Site (nested within depth and habitat) was treated as a random effect and did not significantly affect multivariate elemental signatures (permutational MANOVA, PERMANOVA, $\mathrm{p}<0.05$ ). For subsequent tests, data were therefore pooled across sites within each habitat/depth. Multivariate elemental signatures were compared between depths and among 
habitats using PERMANOVA. Data were first normalised to account for inter-elemental variation interelemental variation in concentration ranges. Withingroup variability in multivariate elemental signatures was compared using permutational homogeneity of dispersion (PERMDISP) tests, which use the ANOVA $F$ statistic to compare distances of observations from their group centroid; p-values are obtained under permutation of least-squares residuals, thereby avoiding the assumptions of normality of distribution and homogeneity of variance associated with traditional dispersion tests such as Levene's test (Levene 1960). Canonical analysis of principal coordinates (CAP, Anderson \& Willis 2003), was used to calculate leave-one-out reclassification success rates to experimental group. Principal coordinate analysis (PCO) was used to construct an unconstrained ordination with which to visualise spatial variability in multivariate signatures; axes display eigenvectors, standardised by the square-root of their corresponding eigenvalues (Gower 1966, Anderson \& Willis 2003). Permutational ANOVA was used to quantitatively identify the suite of individual elements driving horizontal and vertical trends in multivariate composition. The effects of salinity and growth rate on individual element concentrations were assessed using the distance-based linear model (DistLM) routine. As salinity explained $94 \%$ of the variability in mussel growth rates (Wing \& Leichter 2011), the 2 factors were modelled sequentially to assess whether growth rate explained a significant proportion of the variability in element/Ca ratios given that already explained by salinity.

\section{RESULTS}

\section{Oceanographic survey}

In situ temperature differed between all experimental groups, but the high seasonal variability within the LSL meant that long-term climatological averages did not differ between any experimental groups (Fig. 2). Because of this, and the fact that the LSL is warmer than the SL in the summer but cooler in the winter, salinity was considered a better marker for each water mass than temperature.

In all habitats, salinity increased with depth and became less variable (Fig. 3). Mean surface salinity increased along the fjord axis from $\sim 5$ in the inner fjord to $\sim 15$ in the outer fjord. Surface salinity range in the inner fjord was restricted to $<20$ but in the mid and outer fjord habitats included more oceanic values of $>25$. In the inner fjord the LSL extended to greater depths than in the mid fjord; in the outer fjord the LSL was shallow and already partially mixed with the
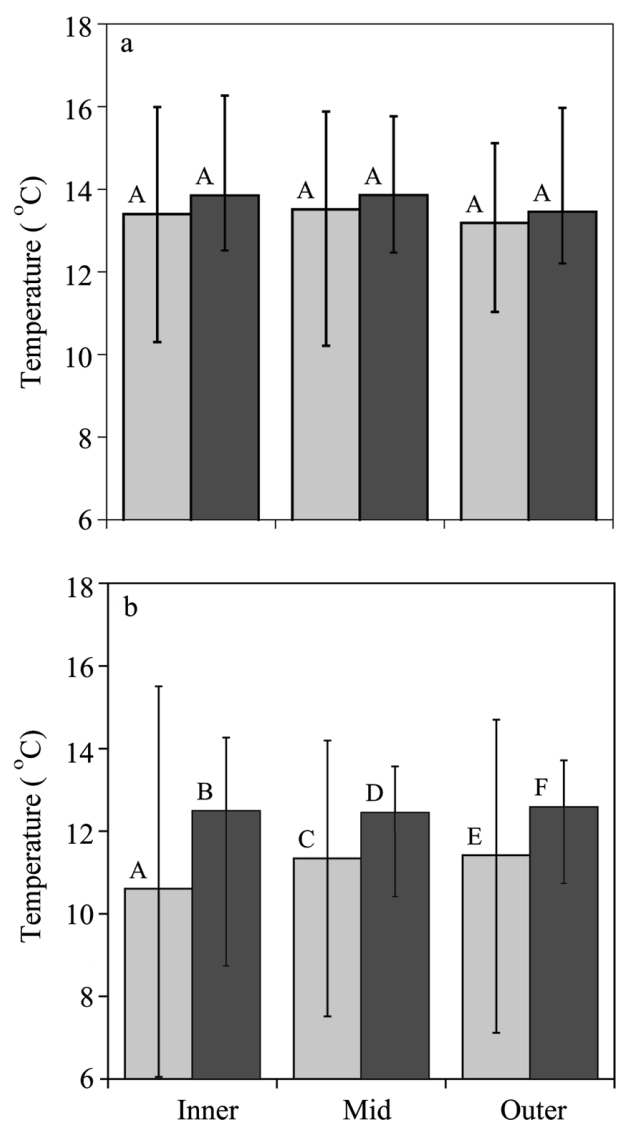

Fig. 2. Oceanographic survey data from Doubtful Sound, New Zealand. (a) Long-term climatological mean temperature and (b) in situ mean temperature during the experimental period in the low salinity layer (LSL, light bars) and underlying saline layer (SL, dark bars) in inner, mid and outer fjord habitats. Error bars show the range of observations. Groups not connected by the same letter are significantly different (PERMANOVA, p < 0.05)

underlying seawater. Mean salinity was significantly lower at $2 \mathrm{~m}$ than $8 \mathrm{~m}$ depth in all habitats (inner fjord, pseudo- $t=20.051, \mathrm{p}=0.0001, \mathrm{df}=70 ; \mathrm{mid}$ fjord, pseudo- $t=11.842, \mathrm{p}=0.0001, \mathrm{df}=62$; outer fjord, pseudo- $t=11.953, \mathrm{p}=0.0001, \mathrm{df}=54)$, with salinity at $8 \mathrm{~m}$ depth typical of fully saline ocean water (Fig. 3d). Within the LSL, salinity increased along the fjord from the inner fjord to the mid fjord (pseudo- $t=2.9639 ; \mathrm{p}=$ 0.0050 ; df $=49$ ) but mid fjord and outer fjord did not differ (pseudo- $t=1.9293 ; \mathrm{p}=0.0618$; df $=43$ ). Within the SL, salinity did not vary between inner and mid fjord habitats (pseudo- $t=0.5064 ; \mathrm{p}=0.6131$; $\mathrm{df}=83$ ) but increased between mid and outer fjord habitats (pseudo- $t=2.8941 ; \mathrm{p}=0.0055 ; \mathrm{df}=73$ ). Salinity was more variable in the LSL than the SL in all habitats (inner fjord, pseudo- $t=10.026, \mathrm{p}=0.0001, \mathrm{df}=70$; $\mathrm{mid}$ fjord, pseudo- $t=10.307, \mathrm{p}=0.0001, \mathrm{df}=62$; outer fjord, pseudo- $t=9.707, \mathrm{p}=0.0001, \mathrm{df}=54)$. 

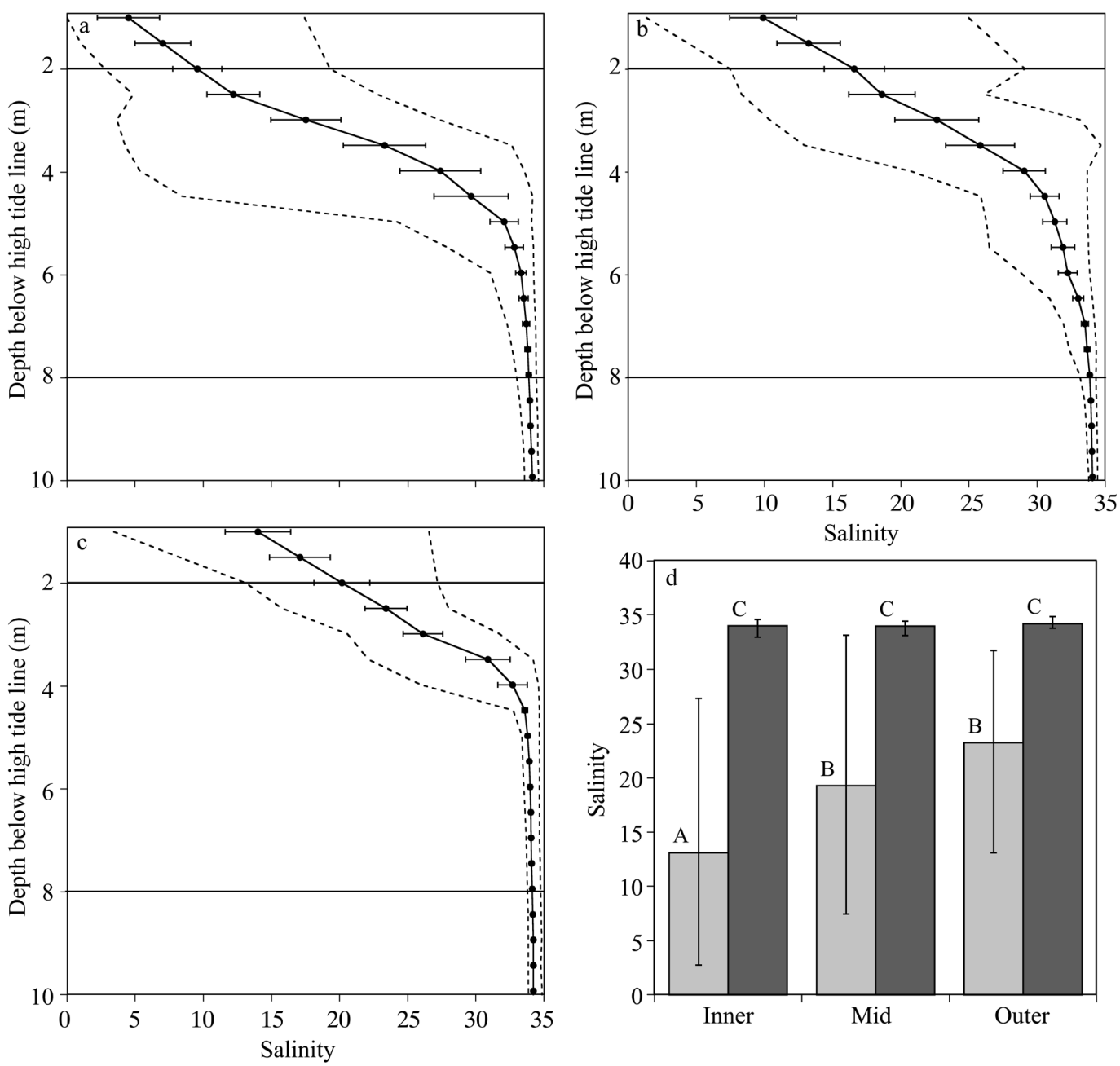

Fig. 3. Salinity profiles for the top $10 \mathrm{~m}$ of the water column in (a) inner (b) mid and (c) outer fjord habitats in Doubtful Sound, New Zealand. Data shown are the long-term climatological mean \pm SE ( $\bullet$ and solid line) and range (dashed lines) for 3 replicate sites in each habitat; the depths of experimental cages $(2$ and $8 \mathrm{~m}$ ) are marked as solid horizontal lines. (d) Mean salinity in the low salinity layer (LSL, light bars) and underlying saline layer (SL, dark bars) in each habitat. Error bars show the range of observations. Groups not connected by the same letter are significantly different (PERMANOVA, $p<0.05$ )

\section{Elemental analysis}

Multivariate trends

Multivariate elemental composition of mussel shells was unaffected by terminal size or growth rate over the experimental period, nested within experimental group ( $\mathrm{p}>0.05)$. Elemental signatures varied significantly among habitats (pseudo- $F_{2,62}=9.068 ; \mathrm{p}=$ 0.0001 ) and between depths (pseudo- $F_{1,62}=15.930 ; p$ $=0.0001$ ). CAP successfully reclassified $73.5 \%$ of samples to their experimental group; 13.2 to $19.1 \%$ would be expected by chance based on sample sizes in each group. The first 2 PCO axes explained $55.7 \%$ of the total variation in trace element signatures: PCO1 separated out samples from the inner fjord LSL and explained $43 \%$ of the variation, while PCO2 sepa- rated remaining samples by depth (Fig. 4). Post-hoc comparisons were made between depths within each habitat and among habitats within each depth and resulted in generally higher reclassification success rates that in all cases exceeded the rate expected by chance alone (Table 2). Multivariate signatures were more dispersed in the LSL than the SL in the inner fjord (pseudo- $t=4.568 ; \mathrm{p}=0.0004 ; \mathrm{df}=62$ ) but not mid (pseudo- $t=0.715 ; \mathrm{p}=0.7718 ; \mathrm{df}=62$ ) or outer fjord habitats (pseudo- $t=0.504 ; \mathrm{p}=0.6722$; df $=62$ ). In the LSL, dispersion decreased significantly along the fjord axis from the inner fjord to mid fjord (pseudo- $t=5.296 ; \mathrm{p}=0.0002 ; \mathrm{df}=62$ ) and outer fjord habitats (pseudo- $t=3.063 ; \mathrm{p}=0.0178$; df $=62$ ). In the SL, no clear trend in dispersion of multivariate elemental signatures was observed among inner, mid and outer fjord habitats. 
Univariate trends

$\mathrm{B} / \mathrm{Ca}, \mathrm{P} / \mathrm{Ca}, \mathrm{Mn} / \mathrm{Ca}, \mathrm{Fe} / \mathrm{Ca}$, $\mathrm{Co} / \mathrm{Ca}, \mathrm{Cu} / \mathrm{Ca}, \mathrm{Sr} / \mathrm{Ca}, \mathrm{Ba} / \mathrm{Ca}$ and $\mathrm{Pb} / \mathrm{Ca}$ varied significantly both between depths and among habitats; $\mathrm{Zn} / \mathrm{Ca}, \mathrm{Cd} / \mathrm{Ca}$ and $\mathrm{Rb} / \mathrm{Ca} \mathrm{did}$ not vary with either depth or habitat overall; Li/Ca varied significantly with habitat but not depth and $\mathrm{Mg} / \mathrm{Ca}$ varied significantly with depth but not habitat (Table 3). Spatial trends in individual elements are shown in Fig. 5 with letters indicating the results of post-hoc PERMANOVA tests. No post-hoc tests were significant for either $\mathrm{Zn}$ or $\mathrm{Rb}$ and these 2 elements are not discussed any further.

$\mathrm{Li} / \mathrm{Ca}$ increased with depth in the inner fjord. Within the LSL, concentrations increased from the inner fjord to mid/outer fjord habitats but in the $\mathrm{SL} \mathrm{Li} / \mathrm{Ca}$ did not differ among

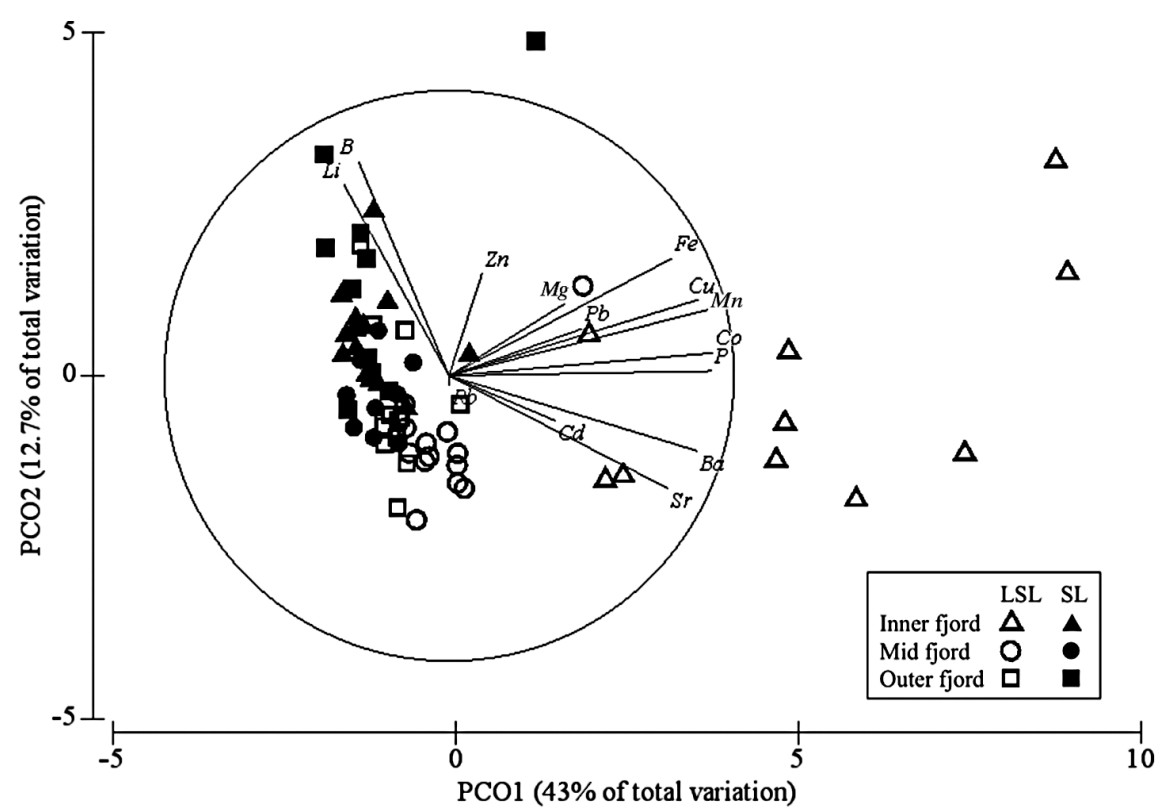

Fig. 4. Mytilus galloprovincialis. Principal coordinate analysis ordination (PCO) of the Euclidean distance between normalised multivariate trace element signatures. $\mathrm{LSL}=$ low salinity layer; $\mathrm{SL}=$ saline layer

habitats. B/Ca increased with depth all habitats. Within the LSL, B/Ca was higher in the outer fjord than the inner or mid fjord. Within the SL, $\mathrm{B} / \mathrm{Ca}$ decreased from inner to mid fjord then increased in the outer fjord.

$\mathrm{Mg} / \mathrm{Ca}$ decreased with depth in the inner fjord. Concentrations decreased along the fjord axis in the LSL, while in the SL Mg/Ca did not differ between habitats. $\mathrm{P} / \mathrm{Ca}, \mathrm{Mn} / \mathrm{Ca}, \mathrm{Fe} / \mathrm{Ca} \mathrm{Co} / \mathrm{Ca}, \mathrm{Cu} / \mathrm{Ca}$ and $\mathrm{Pb} /$ $\mathrm{Ca}$ were significantly elevated in mussels grown in the inner fjord LSL. Concentrations of $\mathrm{Fe}, \mathrm{Cu}$ and $\mathrm{Pb}$ did not vary amongst other experimental groups. Co/ Ca decreased along the fjord axis from inner to outer fjord in the LSL; Mn/Ca decreased from inner to mid/outer fjord in the SL.

Table 2. Mytilus galloprovincialis. Leave-one-out reclassification to group success rates for inner, mid and outer fjord (Habitat) and from the low salinity layer (LSL) and underlying saline layer (SL) (Depth). The reclassification success rate predicted by chance alone and sample sizes are given for each experimental group

\begin{tabular}{|lcccc|}
\hline Habitat & Depth & Success (\%) & Chance (\%) & $\mathrm{n}$ \\
\hline Inner & LSL & 90 & 14.7 & 10 \\
& SL & 76.9 & 19.1 & 13 \\
Mid & LSL & 76.9 & 19.1 & 13 \\
& SL & 88.9 & 13.2 & 9 \\
\multirow{4}{*}{ Outer } & LSL & 33.3 & 17.6 & 12 \\
& SL & 81.8 & 16.2 & 11 \\
\hline
\end{tabular}

Sr/Ca decreased along the fjord axis in the LSL while concentrations in the SL increased from inner to mid fjord then decreased in the outer fjord. For all habitats, concentrations decreased with depth.

$\mathrm{Cd} / \mathrm{Ca}$ decreased with depth in the inner fjord. In the SL Cd/Ca increased between inner and outer fjord habitats, with mid fjord concentrations intermediate.

$\mathrm{Ba} / \mathrm{Ca}$ was significantly elevated in the inner fjord LSL relative to other experimental groups but decreased with depth in all habitats. Concentrations decreased along the fjord axis from inner to mid/outer fjord in the LSL but increased from inner to outer fjord in the SL.

\section{Correlation with salinity and growth rate}

Mean element/Ca ratios were regressed against mean salinity at each depth in inner, mid and outer fjord habitats. Salinity was positively correlated with $\mathrm{Li} / \mathrm{Ca}$ and negatively correlated with $\mathrm{Sr} / \mathrm{Ca}$ and $\mathrm{Ba} / \mathrm{Ca}$ (Table 4). Concentrations of each element in individual shells were regressed against growth rate during the experimental period. Growth rate was positively correlated with $\mathrm{Li} / \mathrm{Ca}$ and negatively correlated with Sr/Ca and $\mathrm{Ba} / \mathrm{Ca}$ (Table 4). Modelling salinity and then growth rate sequentially, growth did not explain a significant portion of the variability in element/Ca given that explained by salinity for any element. 
Table 3. Mytilus galloprovincialis. Results of PERMANOVA tests comparing the concentration relative to $\mathrm{Ca}$ of individual trace elements in mussel shells from the inner, mid and outer fjord (Habitat, pooled across Depths) and from the low salinity layer (LSL) and underlying saline layer (SL) (Depth, pooled across Habitats), including the test statistic pseudo- $F$, the significance level $p$ calculated under permutation, the number of unique values obtained from 9999 permutations and the degrees of freedom (factor, error). Significant results $(p<0.05)$ are shown in bold

\begin{tabular}{|c|c|c|c|c|c|}
\hline Element & Test & Pseudo- $F$ & $\mathrm{p}$ & $\begin{array}{l}\text { Unique } \\
\text { values }\end{array}$ & df \\
\hline $\mathrm{Li} / \mathrm{Ca}$ & $\begin{array}{l}\text { Habitat } \\
\text { Depth }\end{array}$ & $\begin{array}{l}2.2023 \\
12.841\end{array}$ & $\begin{array}{l}0.1163 \\
\mathbf{0 . 0 0 0 4}\end{array}$ & $\begin{array}{l}9949 \\
9818\end{array}$ & $\begin{array}{l}2,67 \\
1,67\end{array}$ \\
\hline $\mathrm{B} / \mathrm{Ca}$ & $\begin{array}{l}\text { Habitat } \\
\text { Depth }\end{array}$ & $\begin{array}{l}25.320 \\
30.150\end{array}$ & $\begin{array}{l}0.0001 \\
0.0001\end{array}$ & $\begin{array}{l}9960 \\
9824\end{array}$ & $\begin{array}{l}2,67 \\
1,67\end{array}$ \\
\hline $\mathrm{Mg} / \mathrm{Ca}$ & $\begin{array}{l}\text { Habitat } \\
\text { Depth }\end{array}$ & $\begin{array}{l}4.6558 \\
2.4588\end{array}$ & $\begin{array}{l}\mathbf{0 . 0 1 4 5} \\
0.1197\end{array}$ & $\begin{array}{l}9958 \\
9817\end{array}$ & $\begin{array}{l}2,67 \\
1,67\end{array}$ \\
\hline $\mathrm{P} / \mathrm{Ca}$ & $\begin{array}{l}\text { Habitat } \\
\text { Depth }\end{array}$ & $\begin{array}{l}22.550 \\
27.700\end{array}$ & $\begin{array}{l}0.0001 \\
0.0001\end{array}$ & $\begin{array}{l}9946 \\
9837\end{array}$ & $\begin{array}{l}2,67 \\
1,67\end{array}$ \\
\hline $\mathrm{Mn} / \mathrm{Ca}$ & $\begin{array}{l}\text { Habitat } \\
\text { Depth }\end{array}$ & $\begin{array}{l}29.635 \\
15.443\end{array}$ & $\begin{array}{l}0.0001 \\
0.0001\end{array}$ & $\begin{array}{l}9958 \\
9824\end{array}$ & $\begin{array}{l}2,67 \\
1,67\end{array}$ \\
\hline $\mathrm{Fe} / \mathrm{Ca}$ & $\begin{array}{l}\text { Habitat } \\
\text { Depth }\end{array}$ & $\begin{array}{l}6.2237 \\
5.7031\end{array}$ & $\begin{array}{l}0.0019 \\
0.0152\end{array}$ & $\begin{array}{l}9963 \\
9847\end{array}$ & $\begin{array}{l}2,67 \\
1,67\end{array}$ \\
\hline $\mathrm{Co} / \mathrm{Ca}$ & $\begin{array}{l}\text { Habitat } \\
\text { Depth }\end{array}$ & $\begin{array}{l}25.901 \\
22.966\end{array}$ & $\begin{array}{l}0.0001 \\
0.0001\end{array}$ & $\begin{array}{l}9952 \\
9846\end{array}$ & $\begin{array}{l}2,67 \\
1,67\end{array}$ \\
\hline $\mathrm{Cu} / \mathrm{Ca}$ & $\begin{array}{l}\text { Habitat } \\
\text { Depth }\end{array}$ & $\begin{array}{l}13.274 \\
16.843\end{array}$ & $\begin{array}{l}0.0002 \\
0.0002\end{array}$ & $\begin{array}{l}9937 \\
9826\end{array}$ & $\begin{array}{l}2,67 \\
1,67\end{array}$ \\
\hline $\mathrm{Zn} / \mathrm{Ca}$ & $\begin{array}{l}\text { Habitat } \\
\text { Depth }\end{array}$ & $\begin{array}{l}0.0950 \\
0.4077\end{array}$ & $\begin{array}{l}0.8919 \\
0.5306\end{array}$ & $\begin{array}{l}9955 \\
9874\end{array}$ & $\begin{array}{l}2,67 \\
1,67\end{array}$ \\
\hline $\mathrm{Rb} / \mathrm{Ca}$ & $\begin{array}{l}\text { Habitat } \\
\text { Depth }\end{array}$ & $\begin{array}{l}0.4545 \\
1.3144\end{array}$ & $\begin{array}{l}0.7778 \\
0.3008\end{array}$ & $\begin{array}{l}9947 \\
9931\end{array}$ & $\begin{array}{l}2,67 \\
1,67\end{array}$ \\
\hline $\mathrm{Sr} / \mathrm{Ca}$ & $\begin{array}{l}\text { Habitat } \\
\text { Depth }\end{array}$ & $\begin{array}{l}24.490 \\
168.83\end{array}$ & $\begin{array}{l}0.0001 \\
0.0001\end{array}$ & $\begin{array}{l}9948 \\
9819\end{array}$ & $\begin{array}{l}2,67 \\
1,67\end{array}$ \\
\hline $\mathrm{Cd} / \mathrm{Ca}$ & $\begin{array}{l}\text { Habitat } \\
\text { Depth }\end{array}$ & $\begin{array}{l}1.3989 \\
1.1842\end{array}$ & $\begin{array}{l}0.2477 \\
0.3231\end{array}$ & $\begin{array}{l}9945 \\
9883\end{array}$ & $\begin{array}{l}2,67 \\
1,67\end{array}$ \\
\hline $\mathrm{Ba} / \mathrm{Ca}$ & $\begin{array}{l}\text { Habitat } \\
\text { Depth }\end{array}$ & $\begin{array}{l}38.963 \\
143.14\end{array}$ & $\begin{array}{l}0.0001 \\
0.0001\end{array}$ & $\begin{array}{l}9942 \\
9858\end{array}$ & $\begin{array}{l}2,67 \\
1,67\end{array}$ \\
\hline $\mathrm{Pb} / \mathrm{Ca}$ & $\begin{array}{l}\text { Habitat } \\
\text { Depth }\end{array}$ & $\begin{array}{l}5.6093 \\
7.0432\end{array}$ & $\begin{array}{l}0.0003 \\
0.0007\end{array}$ & $\begin{array}{l}9952 \\
9914\end{array}$ & $\begin{array}{l}2,67 \\
1,67\end{array}$ \\
\hline
\end{tabular}

\section{DISCUSSION}

The results presented here indicate horizontal and vertical trends in the variability of mussel shell elemental concentrations that reflect sources and mixing of water masses along the axis and with depth in Doubtful Sound. Within the LSL, multivariate elemental signatures were most dispersed in the inner fjord - presumably due to highly variable freshwater inputs and only in the inner fjord habitat did dispersion differ between depths - reflecting the increased mixing of water layers along the fjord axis. The salinity regime and estuarine mixing processes in Doubtful Sound have been discussed in detail elsewhere and oceanographic data presented here reflect previously described patterns
Table 4. Mytilus galloprovincialis. Details of linear regressions of mean element/Ca versus Salinity and Growth rate, including the regression equation, $\mathrm{R}^{2}$ values, and $\mathrm{p}$-values calculated under permutation. Significant regressions $(\mathrm{p}<$ 0.05) are shown in bold

\begin{tabular}{|c|c|c|c|c|}
\hline Element & Factor & Equation & $\mathrm{R}^{2}$ & $\mathrm{p}$ \\
\hline \multirow[t]{2}{*}{$\mathrm{Li} / \mathrm{Ca}$} & Salinity & $\mathrm{Li}=0.0039+0.0004$ & 0.88 & 0.0015 \\
\hline & Growth & $\mathrm{Li}=0.0090+0.0364$ & 0.89 & 0.0108 \\
\hline \multirow[t]{2}{*}{$\mathrm{B} / \mathrm{Ca}$} & Salinity & $\mathrm{B}=0.0311+0.0016$ & 0.46 & 0.1449 \\
\hline & Growth & $\mathrm{B}=0.0547+0.1031$ & 0.29 & 0.2842 \\
\hline \multirow[t]{2}{*}{$\mathrm{Mg} / \mathrm{Ca}$} & Salinity & $\mathrm{Mg}=5.5216-0.0356$ & 0.40 & 0.1334 \\
\hline & Growth & $\mathrm{Mg}=5.1378-2.9501$ & 0.43 & 0.1468 \\
\hline \multirow[t]{2}{*}{$\mathrm{P} / \mathrm{Ca}$} & Salinity & $\mathrm{p}=6.2186-0.1637$ & 0.56 & 0.0614 \\
\hline & Growth & $\mathrm{p}=4.6375-12.530$ & 0.69 & 0.0557 \\
\hline \multirow[t]{2}{*}{$\mathrm{Mn} / \mathrm{Ca}$} & Salinity & $\mathrm{Mn}=6.9681-0.1795$ & 0.43 & 0.1308 \\
\hline & Growth & $\mathrm{Mn}=5.3120-15.713$ & 0.55 & 0.1494 \\
\hline \multirow[t]{2}{*}{$\mathrm{Fe} / \mathrm{Ca}$} & Salinity & $\mathrm{Fe}=0.1145-0.0024$ & 0.44 & 0.1011 \\
\hline & Growth & $\mathrm{Fe}=0.0909-0.2137$ & 0.54 & 0.1120 \\
\hline \multirow[t]{2}{*}{$\mathrm{Co} / \mathrm{Ca}$} & Salinity & $\mathrm{Co}=7.1672-0.1490$ & 0.51 & 0.0712 \\
\hline & Growth & $\mathrm{Co}=5.7112-13.137$ & 0.62 & 0.1175 \\
\hline \multirow[t]{2}{*}{$\mathrm{Cu} / \mathrm{Ca}$} & Salinity & $\mathrm{Cu}=8.3198-0.1920$ & 0.54 & 0.0523 \\
\hline & Growth & $\mathrm{Cu}=6.4424-16.925$ & 0.66 & 0.0643 \\
\hline \multirow[t]{2}{*}{$\mathrm{Sr} / \mathrm{Ca}$} & Salinity & $\mathrm{Sr}=2.5250-0.0335$ & 0.92 & 0.0011 \\
\hline & Growth & $\mathrm{Sr}=2.1126-2.5018$ & 0.81 & 0.0174 \\
\hline \multirow[t]{2}{*}{$\mathrm{Cd} / \mathrm{Ca}$} & Salinity & $\mathrm{Cd}=0.0865-0.0008$ & 0.38 & 0.1023 \\
\hline & Growth & $\mathrm{Cd}=0.0791-0.0743$ & 0.50 & 0.1042 \\
\hline \multirow[t]{2}{*}{$\mathrm{Ba} / \mathrm{Ca}$} & Salinity & $\mathrm{Ba}=4.8654-0.1303$ & 0.75 & 0.0136 \\
\hline & Growth & $\mathrm{Ba}=3.5318-11.177$ & 0.86 & 0.0260 \\
\hline \multirow[t]{2}{*}{$\mathrm{Pb} / \mathrm{Ca}$} & Salinity & $\mathrm{Pb}=0.8975-0.0258$ & 0.52 & 0.0625 \\
\hline & Growth & $\mathrm{Pb}=0.6555-2.3339$ & 0.67 & 0.0566 \\
\hline
\end{tabular}

(Stanton \& Pickard 1981, Gibbs et al. 2000, Gibbs 2001). However, no study to date has sought to experimentally relate the strong environmental gradients that characterise the system to the incorporation of elements into calcified biogenic structures. The ratios of individual elements to calcium that we observed were consistent with varying degrees and directions of environmental and biological control. Identification of these relationships in situ is critical to interpret environmental influences on biogenic carbonate formation and composition and to reconstruct larval and adult dispersal patterns in estuarine systems with strong physico-chemical gradients between water masses.

\section{Evidence for environmental control of elemental uptake}

Several trace elements $(\mathrm{P}, \mathrm{Mn}, \mathrm{Fe}, \mathrm{Co}, \mathrm{Cu}, \mathrm{Cd}, \mathrm{Pb})$ were markedly concentrated in the shells of mussels grown in the inner fjord LSL. As none of these elements were directly correlated with salinity, there are 2 possible explanations for this: (1) fluvial inputs to the inner fjord (including from the HEP outflow) contain 

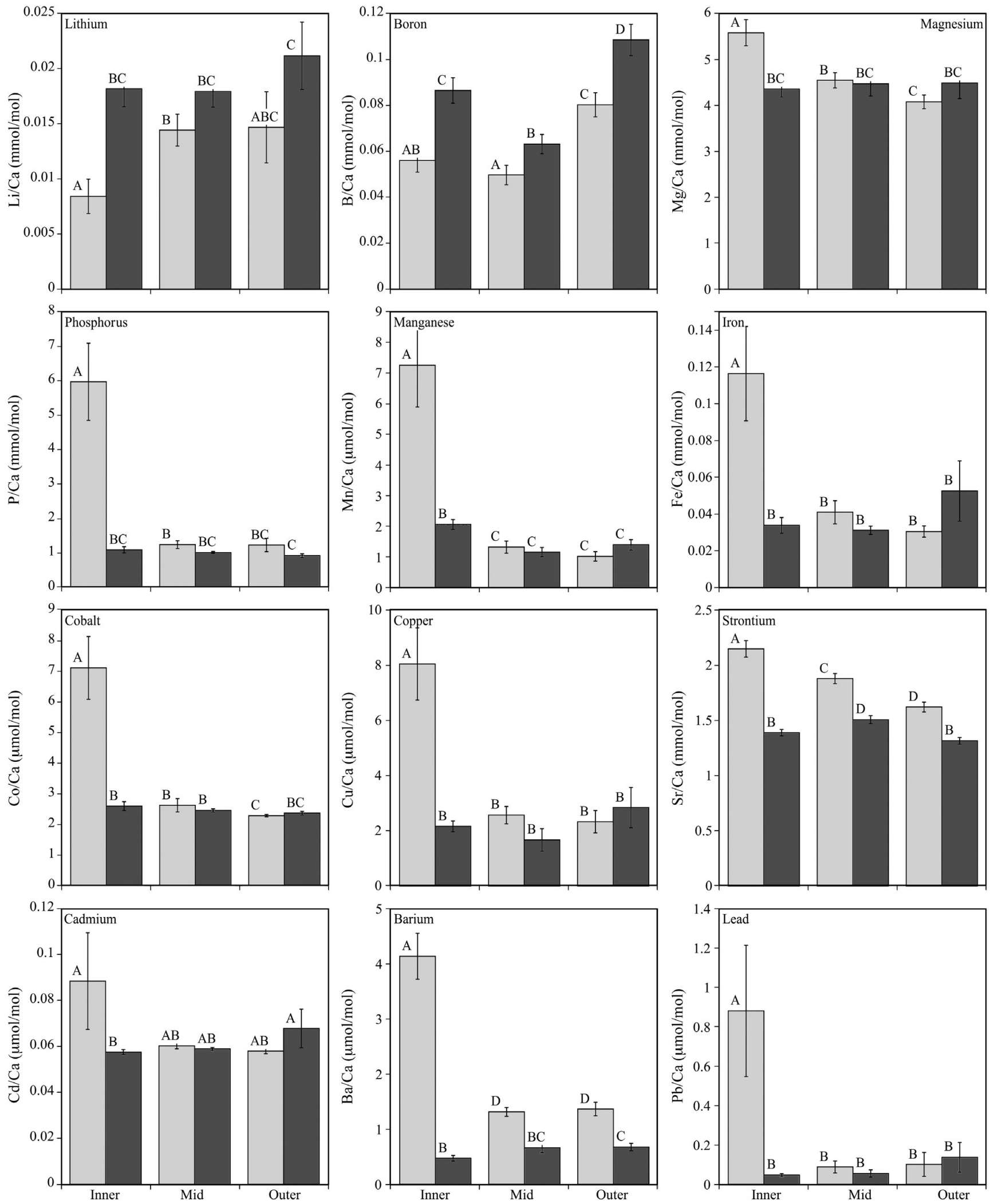

Fig. 5. Mytilus galloprovincialis. Concentrations relative to Ca of each element in mussel shells from the low salinity layer (LSL, light bars) and underlying saline layer (SL, dark bars) in inner, mid and outer fjord habitats. Means \pm SE. Groups not connected by the same letter are significantly different (PERMANOVA, $\mathrm{p}<0.05$ ) 
relatively high levels of trace elements, possibly of anthropogenic origin, or (2) the concentration of bioavailable free ions is sufficiently elevated at the low salinities experienced by this experimental group to account for the increased uptake.

$\mathrm{P}$ is typically elevated in areas with high agricultural runoff; while Doubtful Sound is a relatively pristine body of water, it is the only fjord in the Fiordland system that could potentially receive agricultural runoff via the HEP tailrace. $\mathrm{PO}_{4}{ }^{3-}$ levels and sources in Lakes Manapouri and Te Anau are not known, but are expected to be low relative to the global freshwater average as surrounding land is predominantly native forest and tussock grasslands (Reid et al. 1999). Peake et al. (2001) observed that $\mathrm{PO}_{4}{ }^{3-}$ levels were much lower in the LSL than in the SL, which receives inputs through the renewal of basin water across the sill. However, concentrations within the upper $10 \mathrm{~m}$ of the water column were relatively uniform. Mussels growing at $8 \mathrm{~m}$ depth are unlikely to have received any of the oceanic $\mathrm{PO}_{4}{ }^{3-}$ entering the fjord over the sill and all experimental animals were likely growing in relatively $\mathrm{PO}_{4}{ }^{3-}$-deplete waters. The scant topsoil and minimal natural inputs to the system from runoff would suggest that the tailrace water introduces relatively high $\mathrm{PO}_{4}{ }^{3-}$ water to the fjord. The initial decline in surface concentrations over the first $\sim 7 \mathrm{~km}$ from the tailrace tunnel, followed by a steady increase due to mixing with higher $\mathrm{PO}_{4}{ }^{3-}$ neritic water (Peake et al. 2001) lend support to this hypothesis.

Other elements with marked maxima in the inner fjord LSL are metals typically indicative of anthropogenic activity $(\mathrm{Mn}, \mathrm{Fe}, \mathrm{Co}, \mathrm{Cu}, \mathrm{Cd}$ and $\mathrm{Pb})$, which could potentially be elevated in HEP outflow water. Trace element concentrations in Lake Manapouri are relatively low (Reid et al. 1999) but may still exceed ambient concentrations in the naturally pristine waters of Doubtful Sound.

Mean $\mathrm{Cu}$ concentrations in Lakes Manapouri and Te Anau are around 5.25 to $6.37 \mathrm{nmol} \mathrm{l}^{-1}$ (Reid et al. 1999, Sander et al. 2005). Cu concentrations at $15 \mathrm{~m}$ depth in inner Doubtful Sound in April 2009 were much lower (on average $0.01 \pm 0.003 \mathrm{nmol} \mathrm{l}^{-1}$; S. R. Wing unpubl. data) supporting the hypothesis that the high concentrations observed in mussels grown in the inner fjord LSL result from anthropogenic $\mathrm{Cu}$ inputs via the HEP outflow, although the alternative bioavailability hypothesis must also be considered.

Surface concentrations of $\mathrm{Mn}\left(25-55 \mathrm{nmol} \mathrm{l}^{-1}\right)$ and Fe (350-730 $\mathrm{nmol} \mathrm{l}^{-1}$ ) in Doubtful Sound are relatively low (Kim et al. 1990); vertical profiles were similar in Doubtful Sound and the adjacent, unaltered Bradshaw Sound basin and largely mirrored silicate distribution (i.e. followed a nutrient-type profile). No data are available for $\mathrm{Mn}$ or Fe concentrations in Lakes Man- apouri or Te Anau; while the source of the inner fjord LSL Mn and Fe spikes cannot be ascribed in the absence of comparable ambient water concentration data, the fact that concentrations were not elevated in the surface waters of inner Doubtful Sound (Kim et al. 1990) makes it unlikely that the relatively high concentrations recorded in the shells of mussels grown here result from anthropogenic inputs. Rather, the pattern may be related to the increased concentration of bioavailable free ions at low salinities. This mechanism could also explain the $\mathrm{Cu}$ peak in the inner fjord LSL group.

Dissolved $\mathrm{Cd}$ concentration in Lake Manapouri is around $0.022 \mathrm{nmol} \mathrm{l}^{-1}$ (Sander et al. 2007). However, surface concentrations in Doubtful Sound and Bradshaw Sound are much lower (0.008-0.010 $\left.\mathrm{nmol} \mathrm{l}^{-1}\right)$, increasing with depth in parallel with $\mathrm{PO}_{4}{ }^{3-}$ and comparable between fjord basins (Kim et al. 1990, Frew \& Hunter 1995). The increased $\mathrm{Cd} / \mathrm{Ca}$ observed in mussels grown in the inner Doubtful Sound LSL therefore likely results from an increased concentration of the bioavailable $\mathrm{Cd}^{2+}$ ion at lower salinities rather than anthropogenic inputs of Cd via the HEP outflow. Ambient concentrations of $\mathrm{Co}$ and $\mathrm{Pb}$ in Lake Manapouri and Doubtful Sound are unknown so the mechanism underlying the spatial variability in their incorporation into mussel shell cannot be postulated. The suite of elements displaying an inner fjord LSL peak represent potentially useful natural tags of inner fjord habitat use in Doubtful Sound and low salinity environments in other estuarine systems.

$\mathrm{Ba} / \mathrm{Ca}$ was also elevated in mussels from the inner fjord LSL but this was not unexpected given the inverse relationship between salinity and Ba in seawater, and $\mathrm{Ba} / \mathrm{Ca}$ correlated well with salinity throughout the fjord. Ambient $\mathrm{Ba}$ concentration at $15 \mathrm{~m}$ depth in Doubtful Sound and Bradshaw Sound in April 2009 followed similar trends within and among habitats but was higher in Doubtful Sound than Bradshaw Sound, reflecting the typically lower salinities in the altered fjord basin (S. R. Wing unpubl. data). The marked $\mathrm{Ba} / \mathrm{Ca}$ maximum was therefore likely due to the magnitude of the salinity gradient between this experimental group and other groups and/or an increased concentration of free $\mathrm{Ba}^{2+}$ ions at very low salinities. The along-fjord increase in $\mathrm{Ba} / \mathrm{Ca}$ in the SL mirrors an increase in ambient Ba at $15 \mathrm{~m}$ under constant salinity conditions (S. R. Wing unpubl. data).

$\mathrm{B} / \mathrm{Ca}$ and $\mathrm{Mg} / \mathrm{Ca}$ did not correlate well with salinity despite previous reports of a direct relationship in mytilids (Dodd 1965, Furst et al. 1976, Lorens \& Bender 1980). B/Ca concentrations were lower in the midfjord, perhaps indicating a removal from the water column and reflecting the maximal phytoplankton productivity in this mixing zone (Goebel et al. 2005); 
variability in $\mathrm{B} / \mathrm{Ca}$ at constant salinity likely reflects variability in inputs and ambient concentrations. $\mathrm{Mg} / \mathrm{Ca}$ concentrations were characterised by an inner fjord LSL maximum that drove all observed horizontal and vertical patterns. A salinity effect on Mg incorporation into mussel shells may be detectable only at extremely low salinities, as suggested by Dodd \& Crisp (1982). Li/Ca was well correlated with salinity, corroborating previous experimental results for fish otoliths (Hicks et al. 2010). However, contrary to the Sr profile in seawater, $\mathrm{Sr} / \mathrm{Ca}$ of Mytilus galloprovincialis shells was inversely related to salinity. Ambient Sr concentration at $15 \mathrm{~m}$ depth in inner Doubtful Sound in April $2009\left(0.20 \pm 0.003 \mu \mathrm{mol} \mathrm{l^{-1 }}\right.$; S. R. Wing unpubl. data) exceeds the depth-averaged concentration in Lake Manapouri $\left(0.18 \pm 0.0002 \mu \mathrm{mol} \mathrm{l}{ }^{-1}\right.$; Reid et al. 1999). This is consistent with a conservative profile in seawater and is corroborated by the uniform concentration at $15 \mathrm{~m}$ depth along the fjord axis, at a constant salinity of $\sim 34$. Sr/Ca on the other hand showed significant variability despite constant salinity in the SL. Sr uptake must therefore be influenced by factors other than salinity.

\section{Evidence for biological control of elemental uptake}

Early studies suggested an effect of growth rate on Sr/Ca in bivalve shells (Swan 1957, Pilkey \& Goodell 1963). A direct relationship between growth rate and $\mathrm{Sr} / \mathrm{Ca}$ has been observed by some researchers (Stecher et al. 1996, Takesue \& van Geen 2004) while others (Gillikin et al. 2005b) have found evidence of an inverse relationship. This discrepancy suggests that $\mathrm{Sr}^{2+}$ discrimination could occur either: (1) during transport to the EPF, due to decreased growth rates at higher mantle metabolic activity (Rosenberg \& Hughes 1991), resulting in a direct relationship (Klein et al. 1996), or (2) during shell crystallisation, as although $\mathrm{Sr}^{2+}$ and $\mathrm{Ca}^{2+}$ use similar pathways (Ferrier-Pagès et al. 2002) the enzyme that controls calcium channel activity $\left(\mathrm{Ca}^{2+}\right.$-ATPase) has a higher affinity for $\mathrm{Ca}^{2+}(\mathrm{Yu} \&$ Inesi 1995), resulting in an inverse relationship (Gillikin et al. 2005b). Carré et al. (2006) in their study of 2 bivalve species concluded that the first mechanism was responsible for the observed $\mathrm{Sr}^{2+}$ discrimination as crystal growth rate determines the electrochemical potential driving ions through calcium channels and therefore influences $\mathrm{Sr}^{2+}$ incorporation. However, Gillikin et al. (2005b) dispute this mechanism on the grounds that increased metabolic pumping should result in increased growth rate and a decreased Sr/Ca. Previous studies on mytilids have not reported a relationship between shell growth rate and Sr/Ca (Lorens \& Bender 1980, Klein et al. 1996).
The growth rate of experimental Mytilus galloprovincialis was positive at all depths $(2-10 \mathrm{~m})$ in all habitats in Doubtful Sound except at $2 \mathrm{~m}$ depth in the inner fjord (Wing \& Leichter 2011). Here, growth rate was negligible over the experimental period and shell samples acquired for trace element analysis were minimal. This was attributed to the stressful salinity regime in this habitat; indeed, mussels are naturally absent from this experimental site. Salinity was found to account for $94 \%$ of the variance in growth rate among habitats and depths and a direct relationship was observed (Wing \& Leichter 2011), generating the hypothesis that it is growth rate that is responsible for the observed Sr uptake pattern rather than a direct effect of salinity. While both salinity and growth rates individually explained significant portions of the variability in $\mathrm{Sr} / \mathrm{Ca}(<92 \%)$, salinity emerged as the stronger influence in terms of variance explained. However, physiological mediation of Sr transport between the ambient water and the crystallizing shell is sufficient to result in an inverse relationship between $\mathrm{Sr} / \mathrm{Ca}$ and salinity, rather than the direct relationship previously reported for bivalve shells (Dodd \& Crisp 1982, Raith et al. 1996) and fish otoliths (Campana 1999). Following the model proposed by Gillikin et al. (2005b), the decrease in $\mathrm{Sr}^{2+}$ incorporation at higher salinities may be related to increased crystal growth rate and preferential transport of $\mathrm{Ca}^{2+}$ ions to the site of crystallisation. This is the first evidence suggesting an effect of growth rate on Sr incorporation in a mytilid. Both growth rate (Wing \& Leichter 2011) and salinity were constant in the SL however, so the along-fjord variability in Sr/Ca remains unexplained. The use of high-spatial-resolution analytical techniques such as laser ablation ICP-MS could help resolve the relationship between $\mathrm{Sr}$ incorporation and instantaneous growth rate throughout ontogeny and would also enable targeted sampling of discrete crystalline phases (calcite versus aragonite). This was beyond the scope of the current study and concentrations reported here integrate across crystalline phases. No evidence was found to support physiological control of trace element uptake through valve closure during periods of salinity stress.

As we did not concurrently measure ambient trace element concentrations, we can only postulate relationships between water chemistry and trace element composition of bivalve shell material. For the majority of elements uptake patterns reflected the integration of environmental conditions, either directly as a result of ambient concentrations or indirectly due to increased bioavailability at low salinity. However in the case of $\mathrm{Sr}$, the most well-studied element present in biogenic carbonates and one frequently employed as a proxy for environmental conditions, we found evidence of bio- 
logical mediation of environmental signals via the crystal growth rate. The results of this study, the first to experimentally exploit strong and predictable natural environmental gradients typical of estuaries, provide a valuable addition to the growing body of literature seeking to resolve biological versus physical control of elemental incorporation into biogenic carbonates. This has important implications for future studies seeking to employ environmental variability in elemental signatures of calcified structures as a tool for stock discrimination, connectivity modelling, pollution monitoring and palaeoclimate reconstruction.

Acknowledgements. We thank G. Deane, L. Jack, J. Leichter, A. Lewis, P. Meredith and D. Stokes for their assistance during the field experiment. H. Bowman assisted with oceanographic surveys. A. Hicks and R. McLeod helped prepare samples for analysis. Monetary support was provided by the Royal Society of New Zealand's Marsden Fund (UO-00213 to SRW) and by the Commonwealth Scholarship and Fellowship Plan (NAB).

\section{LITERATURE CITED}

Anderson MJ (2001) Permutation tests for univariate or multivariate analysis of variance and regression. Can J Fish Aquat Sci 58:626-639

Anderson MJ, Willis TJ (2003) Canonical analysis of principal coordinates: a useful method of constrained ordination for ecology. Ecology 84:511-525

Bath Martin G, Thorrold SR (2005) Temperature and salinity effects on magnesium, manganese, and barium incorporation in otoliths of larval and early juvenile spot Leiostomus xanthurus. Mar Ecol Prog Ser 293:223-232

> Becker BJ, Fodrie FJ, McMillan PA, Levin LA (2005) Spatial and temporal variation in trace elemental fingerprints of mytilid mussel shells: a precursor to invertebrate larval tracking. Limnol Oceanogr 50:48-61

Bowman MJ, Dietrich DE, Mladenov PV (1999) Predictions on circulation and mixing in Doubtful Sound, arising from variations in runoff and discharge from the Manapouri Power Station. In: Mooers CNK (ed) Coastal Ocean Prediction. Coastal and Estuarine Studies 56, American Geophysical Union, Washington DC, p 59-76

Bruland KW (1983) Trace elements in sea water. In: Riley JP, Skirrow G (eds) Chemical Oceanography, Vol 8. Academic Press, New York, NY p 157-220

Campana SE (1999) Chemistry and composition of fish otoliths: pathways, mechanisms and applications. Mar Ecol Prog Ser 188:263-297

> Campana SE, Fowler AJ, Jones CM (1994) Otolith elemental fingerprinting for stock identification of Atlantic cod (Gadus morhua) using laser ablation ICPMS. Can J Fish Aquat Sci 51:1942-1950

Carré M, Bentaleb I, Bruguier O, Ordinola E, Barrett NT, Fontugne M (2006) Calcification rate influence on trace element concentrations in aragonitic bivalve shells: evidences and mechanisms. Geochim Cosmochim Acta 70: 4906-4920

> de Vries MC, Gillanders BM, Elsdon TS (2005) Facilitation of barium uptake into fish otoliths: influence of strontium concentration and salinity. Geochim Cosmochim Acta 69: 4061-4072
DiBacco C, Levin LA (2000) Development and application of elemental fingerprinting to track the dispersal of marine invertebrate larvae. Limnol Oceanogr 45:871-880

> Dodd JR (1965) Environmental control of strontium and magnesium in Mytilus. Geochim Cosmochim Acta 29:385-398

> Dodd JR, Crisp EL (1982) Non-linear variation with salinity of $\mathrm{Sr} / \mathrm{Ca}$ and $\mathrm{Mg} / \mathrm{Ca}$ ratios in water and aragonitic bivalve shells and implications for paleosalinity studies. Palaeogeogr Palaeoclimatol Palaeoecol 38:45-56

Elsdon TS, Gillanders BM (2003) Reconstructing migratory patterns of fish based on environmental influences on otolith chemistry. Rev Fish Biol Fish 13:217-235

Ferrier-Pagès C, Boisson F, Allemand D, Tambutté E (2002) Kinetics of strontium uptake in the scleractinian coral Stylophora pistillata. Mar Ecol Prog Ser 245:93-100

Foster LC, Allison N, Finch AA, Andersson C (2009) Strontium distribution in the shell of the aragonite bivalve Arctica islandica. Geochem Geophys Geosyst 10:Q03003 doi: 03010.01029/02007gc001915

> Frew RD, Hunter KA (1995) Cadmium-phosphorus cycling at the subtropical convergence south of New Zealand. Mar Chem 51:223-237

> Furst M, Lowenstam HA, Burnett DS (1976) Radiographic study of distribution of boron in recent mollusk shells. Geochim Cosmochim Acta 40:1381-1386

Gibbs MT (2001) Aspects of the structure and variability of the low-salinity-layer in Doubtful Sound, a New Zealand fiord. N Z J Mar Freshw Res 35:59-72

Gibbs MT, Bowman MJ, Dietrich DE (2000) Maintenance of near-surface stratification in Doubtful Sound, a New Zealand fjord. Estuar Coast Shelf Sci 51:683-704

Gillikin DP, Dehairs F, Baeyens W, Navez J, Lorrain A, André $\mathrm{L}$ (2005a) Inter- and intra-annual variations of $\mathrm{Pb} / \mathrm{Ca}$ ratios in clam shells (Mercenaria mercenaria): a record of anthropogenic lead pollution? Mar Pollut Bull 50: 1530-1540

Gillikin DP, Lorrain A, Navez J, Taylor JW, Keppens E, Baeyens W, Dehairs F (2005b) Strong biological controls on $\mathrm{Sr} / \mathrm{Ca}$ ratios in aragonitic marine bivalve shells. Geochem Geophys Geosyst 6:Q05009 doi:05010.01029/ 02004 gc000874

Gillikin DP, Dehairs F, Lorrain A, Steenmans D, Baeyens W, André L (2006) Barium uptake into the shells of the common mussel (Mytilus edulis) and the potential for estuarine paleo-chemistry reconstruction. Geochim Cosmochim Acta 70:395-407

$>$ Goebel NL, Wing SR, Boyd PW (2005) A mechanism for onset of diatom blooms in a fjord with persistent salinity stratification. Estuar Coast Shelf Sci 64:546-560

Goldsmith JR, Graf DL, Heard HC (1961) Lattice constants of the calcium magnesium carbonates. Am Mineral 46: 453-457

Gower JC (1966) Some distance properties of latent root and vector methods used in multivariate analysis. Biometrika 53:325-338

Hamer PA, Jenkins GP (2007) Comparison of spatial variation in otolith chemistry of two fish species and relationships with water chemistry and otolith growth. J Fish Biol 71:1035-1055

Hicks AS, Closs GP, Swearer SE (2010) Otolith microchemistry of two amphidromous galaxiids across an experimental salinity gradient: a multi-element approach for tracking diadromous migrations. J Exp Mar Biol Ecol 394:86-97

Kim JP, Frew RD, Hunter KA (1990) Trace metal geochemical cycling in the fiord estuaries: Doubtful and Bradshaw Sounds. Eos Trans AGU 71:1100

Klein RT, Lohmann KC, Thayer CW (1996) Sr/Ca and ${ }^{13} \mathrm{C} /{ }^{12} \mathrm{C}$ 
ratios in skeletal calcite of Mytilus trossulus: covariation with metabolic rate, salinity, and carbon isotopic composition of seawater. Geochim Cosmochim Acta 60:4207-4221

Lazareth CE, Vander Putten E, André L, Dehairs F (2003) High-resolution trace element profiles in shells of the mangrove bivalve Isognomon ephippium: a record of environmental spatio-temporal variations? Estuar Coast Shelf Sci 57:1103-1114

Levene H (1960) Robust tests for equality of variances. In: Olkin I, Ghurye SG, Hoeffding W, Madow WG, Mann HB, Levene $\mathrm{H}$ (eds) Contributions to probability and statistics. Stanford University Press, Stanford, CA, p 278-292

> Lorens RB, Bender ML (1980) The impact of solution chemistry on Mytilus edulis calcite and aragonite. Geochim Cosmochim Acta 44:1265-1278

Lorrain A, Gillikin DP, Paulet YM, Chauvaud L, Le Mercier A, Navez J, André L (2005) Strong kinetic effects on Sr/Ca ratios in the calcitic bivalve Pecten maximus. Geology 33:965-968

McCully D, Vennell R, Mladenov PV (1995) Hydrology of a New Zealand fjord. In: Bellwood O, Choat $\mathrm{H}$, Saxena N (eds) Recent advances in marine science and technology 1994. James Cook University, Townsville, p 263-271

Mount AS, Wheeler AP, Paradkar RP, Snider D (2004) Hemocyte-mediated shell mineralization in the eastern oyster. Science 304:297-300

Oliver GJH (1980) Geology of the granulite and amphibolite facies gneisses of Doubtful Sound, Fiordland, New Zealand. NZ J Geol Geophys 23:27-41

> Peake BM, Walls DJ, Gibbs MT (2001) Spatial variations in the levels of nutrients, chlorophyll $a$, and dissolved oxygen in summer and winter in Doubtful Sound, New Zealand. N Z J Mar Freshw Res 35:681-694

Phillips DJH (1976) Common mussel Mytilus edulis as an indicator of pollution by zinc, cadmium, lead and copper. I. Effects of environmental variables on uptake of metals. Mar Biol 38:59-69

Phillips DJH (1977a) Common mussel Mytilus edulis as an indicator of trace metals in Scandinavian waters. I. Zinc and cadmium. Mar Biol 43:283-291

Phillips DJH (1977b) Effects of salinity on net uptake of zinc by common mussel Mytilus edulis. Mar Biol 41:79-88

Phillips DJH (1978) Common mussel Mytilus edulis as an indicator of trace metals in Scandinavian waters. II. Lead, iron and manganese. Mar Biol 46:147-156

Phillips DJH (1995) The chemistries and environmental fates of trace metals and organochlorines in aquatic ecosystems. Mar Pollut Bull 31:193-200

Pilkey OH, Goodell HG (1963) Trace elements in recent mollusk shells. Limnol Oceanogr 8:137-148

Pitts LC, Wallace GT (1994) Lead deposition in the shell of the bivalve Mya arenaria: an indicator of dissolved lead in seawater. Estuar Coast Shelf Sci 39:93-104

Qiu JW, Xie ZC, Wang WX (2005) Effects of calcium on the uptake and elimination of cadmium and zinc in Asiatic clams. Arch Environ Contam Toxicol 48:278-287

Raith A, Perkins WT, Pearce NJG, Jeffries TE (1996) Environmental monitoring on shellfish using UV laser ablation ICP-MS. Fresenius J Anal Chem 355:789-792

Reid MR, Kim JP, Hunter KA (1999) Trace metal and major ion concentrations in Lakes Hayes and Manapouri. J R Soc N Z 29:245-255

Rosenberg GD, Hughes WW (1991) A metabolic model for the determination of shell composition in the bivalve mollusk Mytilus edulis. Lethaia 24:83-96

Rucker JB, Valentine JW (1961) Salinity response of trace element concentration in Crassostrea virginica. Nature 190:1099-1100

Rutger SM, Wing SR (2006) Effects of freshwater input on shallow-water infaunal communities in Doubtful Sound, New Zealand. Mar Ecol Prog Ser 314:35-47

Sander S, Kima JP, Anderson B, Hunter KA (2005) Effect of UVB irradiation on $\mathrm{Cu}^{2+}$-binding organic ligands and $\mathrm{Cu}^{2+}$ speciation in alpine lake waters of New Zealand. Environ Chem 2:56-62

Sander S, Ginon L, Anderson B, Hunter KA (2007) Comparative study of organic $\mathrm{Cd}$ and $\mathrm{Zn}$ complexation in lake waters: seasonality, depth and $\mathrm{pH}$ dependence. Environ Chem 4:410-423

Stanton BR (1984) Some oceanographic observations in the New Zealand fjords. Estuar Coast Shelf Sci 19:89-104

Stanton BR (1986) Winter oceanographic observations in some New Zealand fjords. N Z J Mar Freshw Res 20: 299-314

Stanton BR, Pickard GL (1981) Physical oceanography of the New Zealand fiords. NZ Oceanogr Inst Mem 88:3-37

Stecher HA, Krantz DE, Lord CJ, Luther GW, Bock KW (1996) Profiles of strontium and barium in Mercenaria mercenaria and Spisula solidissima shells. Geochim Cosmochim Acta 60:3445-3456

Strasser CA, Mullineaux LS, Thorrold SR (2008a) Temperature and salinity effects on elemental uptake in the shells of larval and juvenile softshell clams Mya arenaria. Mar Ecol Prog Ser 370:155-169

> Strasser CA, Mullineaux LS, Walther BD (2008b) Growth rate and age effects on Mya arenaria shell chemistry: implications for biogeochemical studies. J Exp Mar Biol Ecol 355: $153-163$

> Swan EF (1957) The meaning of strontium:calcium ratios. Deep-Sea Res 4:71

Takesue RK, van Geen A (2004) Mg/Ca, Sr/Ca and stable isotopes in modern and Holocene Protothaca staminea shells from a northern California coastal upwelling region. Geochim Cosmochim Acta 68:3845-3861

Thorrold SR, Jones GP, Hellberg ME, Burton RS and others (2002) Quantifying larval retention and connectivity in marine populations with artificial and natural markers. Bull Mar Sci 70:291-308

Vander Putten E, Dehairs F, Keppens E, Baeyens W (2000) High resolution distribution of trace elements in the calcite shell layer of modern Mytilus edulis: environmental and biological controls. Geochim Cosmochim Acta 64: 997-1011

Watson EB (1996) Surface enrichment and trace element uptake during crystal growth. Geochim Cosmochim Acta 60:5013-5020

Wilbur KM (1972) Shell formation in molluscs. In: Florkin M, Scheer BT (eds) Chemical zoology VII: Mollusca. Academic Press, New York, NY, p 103-145

> Wing SR, Leichter JJ (2011) Variation in environmental conditions in a subtidal prey refuge: effects of salinity stress, food availability and predation on mussels in a fjord system. Mar Ecol Prog Ser 422:201-210

> Yu X, Inesi G (1995) Variable stoichiometric efficiency of $\mathrm{Ca}^{2+}$ and $\mathrm{Sr}^{2+}$ transport by the sarcoplasmic reticulum ATPase. J Biol Chem 270:4361-4367 